\title{
Reflection of Spiritualism: An Interpretation of Vedanta by Max Mueller and Aurobindo
}

\author{
Dr. Suprita Jha
}

Associate Professor, Department of English, Mata Sundri College, University of Delhi, India

Received: 19 Oct 2020; Received in revised form: 19 Dec 2020; Accepted: 24 Dec 2020; Available online: 31 Dec 2020 C2020 The Author(s). Published by Infogain Publication. This is an open access article under the CC BY license (https://creativecommons.org/licenses/by/4.0/).

\begin{abstract}
The present proposal is an account of the lives of two men who were scholars and thinkers at the same time. I do not think that a man is entitled to such titles only on the strength of his position and fame in his own age, unless in addition he played so important and significant a role in history that he remains an element to be reckoned with in understanding the continuing evolution of a particular people or humanity in general. Max Mueller's position was very impressive in its geographical range, extending from the United States to Japan. When he died, a message came from an Indian Social reformer, Malabari, "All India mourns with you" and that embodied the feelings of all educated Indians. Similarly, Sri Aurobindo was not just a poet or a singer of songs, he was as well a dramatist, a critic and a thinker of great distinction. He is remembered in modern times, more as a great philosopher than as an artist. Sri Aurobindo was a highly educated person, he was a great scholar of such classical languages as Latin and Greek. It is in respect of his scholarship and poetic craftsmanship that he is often compared with John Milton. In the present paper, I plan to explore the mystery and suggestive quality of both these writers which stand for the betterment of human race. And I also propose the techniques by which they have opened the gate of spirituality for everyone. I really appreciate their scholarships that would be exemplary for the contemporary world and for the coming generation.
\end{abstract}

Keywords-Spirituality, morality, scholarship, Vedanta, Knowledge, God, Mythology, Language.

\section{INTRODUCTION}

The Vedantic tradition is concerned with the self-realization by which one understands the ultimate nature of reality, called God or The Supreme Power. Vedanta or Uttara Mimansa is one of the six orthodox schools of Hindu Philosophy. The term Veda means 'Knowledge' and Anta means 'End', and originally referred to the Upanishads, a collection of fundamental texts in Hinduism. Vedanta is the most prominent and philosophically advanced of the orthodox schools and the term Vedanta may also be used to refer to Indian Philosophy more generally. It is also said that, "Vedanta means the purpose or goal of the Vedas." Max Mueller's specialty was the knowledge of Sanskrit which, though a pioneering study when he was young, had hardened into a narrow academic discipline when he died. His relations with India and Indians were a major element in his life and an essential part of his vocation. On the other hand, it was during his detention in the Alipur Jail that Sri Aurobindo had the ineffable mystic experience of "Narayan Darshan", and this episode brought about a radical change in his earlier outlook. He leads us to a twofold discovery which we urgently need if we want not only to find a way out of our suffocating chaos, but also to transform our world. Both these scholars have their own interpretations of the mysticism of life that could be viewed in context with their relationship with the world as well as with the transcendental world.

\section{EXPOSITION}

\section{MAX MULLER:-}

One of the greatest of modern Indians, Swami Vivekananda, the preacher of Neo-Hinduism, once said, "There are a number of great souls in the West who undoubtedly are well-wishers of India, but I am not aware of one in Europe who is a greater well-wisher. He is not only a well-wisher, but also a deep believer in Indian Philosophy and religion." Max Mueller had established that the Indian and the European languages belonged to the same family; that our words, 'pita, mata, duhita' etc. were the same as the English words, 'father, mother, daughter' etc. Max Mueller put 
forward his ideas as explanations of some of the deepest facts of life: religion, mythology and language. It took him five years of continuous labor to complete the editing and printing of only the first volume of his edition of the Rig Veda. He proclaimed the larger purpose of Sanskrit philosophy quite emphatically in the introduction to the first book he wrote on Sanskrit philology : "A History of Ancient Sanskrit Literature", published in 1859. He wrote, "The object and aim of Philology, in its highest sense, is but one, to learn what man is, by learning what man has been. With this principle, we shall never lose ourselves, though engaged in the most minute and abstruse inquiries."

The primary object of Mueller's Sanskrit studies was thus neither philology nor literature as such, but the evolution of religious and philosophical thought. Therefore, he was bound to specialize in Vedic Literature. Mentioning the fact that all later Sanskrit books on religion, law and philosophy refer back to one early and unique authority called by the comprehensive name of the Veda, he wrote: "It is with the Veda, therefore, that Indian philosophy ought to begin if it is to follow a natural and historical course. So great an influence has the Vedanta exercised upon all succeeding periods of Indian history, so closely in every branch of literature connected with Vedic traditions, that it is impossible to find the right point of view for judging of Indian religion, morals and literature without having the knowledge of the Vedanta." His first work in Sanskrit scholarship was a translation of the Hitopadesa. But from the very beginning his main interest was in ideas, and therefore he had been drawn towards the Upanishads, though he had also read Rig Veda.

To Max Muller the Rig Veda which kept him occupied fully or partly for many years was only a means to an end. In fact, his work on Rig Veda could be compared to the experiment carried out by a theoretical physicist. Actually, he would have nothing to do with the 'dis-idealization' of religion. In fact, he led to idealize the ancient religions on account of his respect and love for mankind. Some of his sayings illustrate this strikingly. 'Human nature is divine nature modified.' 'God comes to us in the likeness of man - there is no other God.' So, all his interpretations of religion and mythology, based on his love for man, can be called his Canticles, for in spite of their scientific and philosophical form there is a fervor and vocal exultation in them which come only from spirituality.

\section{SRI AUROBINDO}

As Max Muller represented Europe so gloriously in the field of Vedantic studies, in the same manner, Sri Aurobindo represented India with his much acclaimed works on
Vedanta. It is the glorious tradition of India that sacred scriptures are continually being studied and pondered over. They are often elaborated upon, criticized or confirmed in conjunction with one's own experiences. Sri Aurobindo belongs to this tradition. His technique, based upon his mystical experience is confirmed by the sacred lore of India - the Vedas and the Upanishads. He had studied Western Philosophy and the systems of Plato and Aristotle. He also thoroughly studied the systems of Indian Philosophy. Many a Philosopher seeks to define the nature of the Reality but few can see the light. To Sri Aurobindo, the secret of human existence and of Divinity was unfolded through his mystical experiences. Frequent and forceful revelations had a great impact on his interpretation of Vedanta. He says, "The intellect can only catch fragmentary representation of the truth and not the entire thing itself." His theory is known as Integral Monism. It is different from the Absolute Monism established by Sri Sankaracharya who denies existence on empirical level I relation to the Ultimate Reality whereas Sri Aurobindo accepts existence of life on material level as a device to the life Divine.

Sri Aurobindo says that we should not forget that everything is truly within us, within man's heart. The altar, offering and the rise, the seer, mantra and deity, Brahmana's chanting the Veda, all are within us. The perception or the vision of limitations of all human thought and endeavor to perfect humanity is the beginning of spiritual evolution. Each man then follows a particular line or path according to his capacity with a view to making spiritual emergence possible in him. In fact, according to him, Veda, the treasure house of spiritual knowledge is the heritage of mankind. His interpretation of the Vadas was altogether a new approach, aimed at presenting its positive and constructive spiritual aspect. Actually, he had tried to give a new meaning to Hindu Dharma by arriving at the essential unity of matter, mundane life through a deeper understanding of the super consciousness resulting into divine life. He continued his superhuman effort to make people aware of it till he breathed his last. He was sure of the human cycle leading a divine life.

There is Sri Aurobindo the philosopher, Sri Aurobindo the poet-which he was in essence--- and the visionary of evolution. Sri Aurobindo the explorer-who was also a Yogi and according to him, Yoga is the art of conscious selffinding. It is this exploration of consciousness that he guides us with his philosophical writings. He experienced the presence of the Great Divine in his internal yoga that perhaps has the power to change the meaning of human existence. Thus, after exploring the outermost frontiers of worlds not unknown to ancient wisdom, Sri Aurobindo discovered another world, as yet unmapped, which he called 
Super mind or Super mental. He requests all the Super minds to bring a decisive change in the evolution of of the earth consciousness thet will have the power to transform our material world into a world of meaning and matter.

\section{CONCLUSION}

No one can deny the gifts given by these two eminent scholars in the field of Vedantic studies and its influence on spiritualism. It is quite surprising that even in his early career, Max Muller several times expressed the view that a "reformation within Hinduism needed to occur comparable to the Christian Reformation." In his view, "if there is one thing which a comparative study of religious places in the clearest light, it is the inevitable decay to which every decay to which every religion is exposed." $\mathrm{He}$ used his connections with the Brahmo Samaj to encourage such a reformation on the lines pioneered by Ram Mohan Roy. He once wrote, "The translation of the Veda will hereafter tell to a great extent on the fate of India, and on the growth of millions of souls in that country. It is the root of their religion, and to show them what the root is, is the only way of uprooting all that has sprung from it during the last 3,000 years." We also find a trace of the same understanding of religion in Sri Aurobindo too. While describing the Vedic Philosophy, his synthesis was not a philosophic construct, but a realisation stemming from direct spiritual experience. The great originality of Sri Aurobindo is to have fused the modern scientific concept of evolution with the perennial gnostic experience of an all-pervading divine consciousness supporting all phenomenal spiritual existence.

Friedrich Max Muller was a man of letters. During his lifetime, he translated not only Rig Veda and Upanishad, but also translated a collection of Hitopadesha. He believed that it was very important for the Indian Society to be educated and education could only bring the upliftment in India. He also supported Brahmo Samaj for their progressive thoughts and revolutionary ideas. There is a big controversy regarding the contribution of Max Muller towards Sanskrit language and literature. There are scholars who believe that his translated versions of Rig Veda, Upanishads and some other Sanskrit works are not the true representations of the original texts; on the contrary, he tries to establish the supremacy of Christianity by presenting the orthodox and superstitious preachings of these scriptures of Hinduism. But whatever would be the reality no one can deny his interest and offerings in the field of Sanskrit Literature. Likewise, Sri Aurobindo's prose and poetic writings project him as a great YOGI, a philosopher and a prophetic engineer of the life Divine. His most popular philosophical work with the same title is a treatise on metaphysics. In this book, he has answered some of the frequently asked questions related to the human existence and the life after death. It is noticed that the basic theme of Sri Aurobindo's poems is the relationship between illusion and reality, moment and eternity and the human life and life Divine. Finally, on the basis of the assessment of the writings of both these scholars-from the East and the Westwe can say that both of them belong to a school of writing that may be called the reflective meditative philosophical school of writing. They do have their own contribution to the field of human actuality and religious studies.

\section{REFERENCES}

[1] Satprem: Sri Aurobindo or the Adventure of Consciousness

[2] Aparna Banerjee: Integral Philosophy of Sri Aurobindo

[3] Published by Sri Aurobindo Ashram, Pondicherry: To Be A True Leader-Selections from the Works of Sri Arobindo and the Mother.

[4] Nanda Mookerjee: I Point to India (Selected Writings of Max Muller)

[5] Life Span Research Foundation: Max Muller on Indian Life and Thought. 